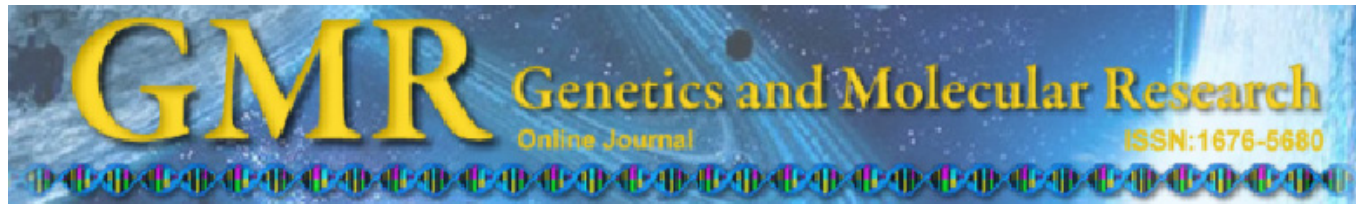

\title{
Sequence variants in the bovine PRDM16 gene associated with body weight in Chinese cattle breeds
}

\author{
J. Wang ${ }^{1}$, C. Wang ${ }^{1}$, R. Tian' ${ }^{1}$, Y.-Z. Huang ${ }^{1}$, X.-S. Lai ${ }^{1}$, X.-Y. Lan ${ }^{1}$, \\ J.-Q. Wang ${ }^{3}$ and H. Chen ${ }^{1,2}$ \\ ${ }^{1}$ Shaanxi Key Laboratory of Molecular Biology for Agriculture, \\ College of Animal Science and Technology, Northwest A\&F University, \\ Yangling, China \\ ${ }^{2}$ Institute of Cellular and Molecular Biology, Xuzhou Normal University, \\ Xuzhou, China \\ ${ }^{3}$ Research Center of Cattle Engineering Technology in Henan, \\ Zhengzhou, China \\ Corresponding author: H. Chen \\ E-mail: chenhong1212@263.cn
}

Genet. Mol. Res. 11 (1): 746-755 (2012)

Received July 7, 2011

Accepted January 3, 2012

Published March 22, 2012

DOI http://dx.doi.org/10.4238/2012.March.22.5

ABSTRACT. As a zinc-finger protein, PR domain containing 16 (PRDM16) controls brown fat determination by stimulating brown fat cell production while suppressing the expression of genes for production of white fat cells; mutations in this domain are associated with myelodysplastic syndrome and leukemogenesis. In our study, polymorphisms in exons $2,3,4,5,7,8$, and 9 of the PRDM16 gene were detected by PCR-SSCP, DNA sequencing and CRS-PCR-RFLP methods in 1031 cattle of the Chinese breeds: Jiaxian, Nanyang, Qinchuan, and Chinese Holstein. Three mutations (NC_007314.3: g.577 G>T, $614 \mathrm{~T}>\mathrm{C}, 212237 \mathrm{~T}>\mathrm{C}$ ) were detected. Animals with the homozygote genotype had lower body weight and average daily gain than those with the other genotypes. PRDM16 gene-specific SNPs may be useful markers for growth traits for marker-assisted selection programs.

Key words: Association; Cattle; PRDM16 gene; Sequence variants 


\section{INTRODUCTION}

The Prdm (PRDI-BF1 and RIZ homology domain containing proto-oncogene transcription factor) family is characterized by an N-terminal PR domain and zinc fingers (except Prdm11) (Jenuwein, 2001). Members of the family play important roles in the development of the mammalian nervous system and the definition of the cell fate.

Among the members of the Prdm family, the PRDM16 gene is involved in mammalian neural class specification and sequential progression of central nervous system neurogenesis (Kinameri et al., 2008). As a Smad binding protein, it is a potential candidate factor for the development of orofacial structures through modulation of the TGF- $\beta$ signaling pathway (Warner et al., 2007). The ability of the PRDM16 gene to control the switch between skeletal muscle and brown fat in mice has attracted a great deal of interest (Seale et al., 2007, 2008). This gene activates a robust brown fat phenotype: on one hand, by binding to peroxisome proliferator-activated receptor- $\gamma$ (PPAR- $\gamma$ ), it stimulates expression of brown fat-producing genes [such as peroxisome proliferator-activated receptor gamma coactivator 1 alpha (PGC-1 $\alpha$ ) and uncoupling protein-1 (UCP1)] (Seale et al., 2007). It also suppresses the expression of genes that code for white fat cells. In humans, research has focused on the potential targets of the PRDM16 gene for the development of obesity-related therapeutics; the intention is to induce the conversion of white adipose tissue (WAT) into brown adipose tissue (BAT) to combat obesity and its related disorders (Kajimura et al., 2008; Farmer, 2008). In beef cattle, deposition of intramuscular fat, or "marbling", contributes significantly to meat quality variables, including juiciness, flavor, and tenderness. The accumulation of intramuscular fat is largely influenced by the genetic background of cattle, as well as their age and nutrition (Wang et al., 2009). Going in the opposite direction, we can induce the conversion of BAT into WAT to improve meat quality. This idea raise some questions. First, as we all know that BAT plays important role in newborns (Cousin et al., 1992), if the adults do not have BAT, there may be problems with developing young. However, accumulating evidence suggests that adults retain metabolically active brown fat (Nedergaard et al., 2007). Another question is whether the PRDM16 gene has the ability to affect bovine growth traits. Along this line, we decided to examine the mutations of the PRDM16 gene in cattle and their association with growth traits.

Jiaxian, Nanyang and Qinchuan cattle are three of the most representative indigenous bovine (Bos taurus) breeds in China; they are designated as nationally protected resources due to their good performance traits and meat characteristics. They are draft and beef dual-purpose cattle breeds and have been selected for beef production for some time, which may have decreased the frequency of variations. The Chinese Holstein is a local dairy breed.

\section{MATERIAL AND METHODS}

\section{Animals}

Four breeds of Chinese indigenous cattle [Jiaxian (JX, N =446); Nanyang (NY, N = 269); Qinchuan (QC, $\mathrm{N}=236)$, and Chinese Holstein $(\mathrm{CH}, \mathrm{N}=80)$ ] were used in this study. The Jiaxian animals were from the breeding farm of Jiaxian cattle (Jiaxian county, Henan Province; $33^{\circ} 58^{\prime} 18^{\prime \prime} \mathrm{N}, 113^{\circ} 12^{\prime} 45^{\prime \prime} \mathrm{E}$ and $114 \mathrm{~m}$ in altitude); the Nanyang animals were from the breeding center of Nanyang cattle (Nanyang city, Henan Province; 32 $59^{\prime} 26^{\prime \prime} \mathrm{N}$, $112^{\circ} 31^{\prime} 42^{\prime \prime E}$ and $130 \mathrm{~m}$ in altitude), and the Qinchuan animals were from the breeding farm of 
Qinchuan cattle and the breeding center of Qinchuan cattle (Fufeng county, Shaanxi Province; $34^{\circ} 21^{\prime} 35^{\prime \prime} \mathrm{N}, 107^{\circ} 52^{\prime} 30^{\prime \prime} \mathrm{E}$ and $560 \mathrm{~m}$ in altitude), and the Chinese Holstein animals were from the breeding farm of milk cattle (in Xi'an city, Shaanxi Province; $34^{\circ} 15^{\prime} 53^{\prime \prime} \mathrm{N}, 108^{\circ} 56^{\prime} 39^{\prime \prime} \mathrm{E}$ and $400 \mathrm{~m}$ in altitude). Henan and Shaanxi Provinces have a continental climate. Only male animals were used. After weaning at six months, they were fed ad libitum on concentrated feed and hay to 24 months of age. The live weight and average daily weight gain of the cattle were determined at the age of $6,12,18$, and 24 months. DNA was isolated from $1 \mathrm{~mL} 2 \%$ heparintreated whole blood samples according to Chen and Leibenguth (1995).

\section{Primers and mutations determined by PCR-SSCP and DNA sequencing}

Based on the bovine PRDM16 gene sequence (GenBank accession No. NC_007314.3), seven pairs of primers were designed to analyze exons $2,3,4,5,7,8$, 9 and their flanking region (there are only $4 \mathrm{bp}$ in exon 1 , so this exon was not included in this study). Details of primers are in Table 1 . The $25-\mu \mathrm{L}$ reaction volume contained 50 ng genomic DNA, $0.5 \mu \mathrm{M}$ of each primer, $1 \mathrm{X}$ buffer (including $1.5 \mathrm{mM} \mathrm{MgCl}_{2}$ ), $200 \mu \mathrm{M}$ dNTPs (dATP, dTTP, dCTP, and dGTP) and 0.625 U Taq DNA polymerase (MBI, Lithuania). Cycling conditions were as follows: an initial denaturing of $5 \mathrm{~min}$ at $95^{\circ} \mathrm{C}$, followed by 35 cycles of denaturation at $94^{\circ} \mathrm{C}$ for $30 \mathrm{~s}$, annealing at $50^{\circ}$ to $66^{\circ} \mathrm{C}$ depending on the primer (see Table 1 for details) for $30 \mathrm{~s}$ and extension at $72^{\circ} \mathrm{C}$ for $35 \mathrm{~s}$, followed by a final extension at $72^{\circ} \mathrm{C}$ for $10 \mathrm{~min}$.

Aliquots of $5 \mu \mathrm{L}$ PCR products from 80 random individuals in four breeds (20 individuals from each breed) were mixed with $5 \mu \mathrm{L}$ denaturing solution ( $95 \%$ formamide, $25 \mathrm{mM}$ EDTA, $0.025 \%$ xylene-cyanole, and $0.025 \%$ bromophenol blue), heated at $98^{\circ} \mathrm{C}$ for $10 \mathrm{~min}$, and immediately chilled on ice. Denatured DNA was subjected to $10 \%$ PAGE (polyacrylamide gel, $80 \mathrm{x}$ $73 \times 0.75 \mathrm{~mm})$ in $1 \mathrm{X}$ TBE buffer and constant voltage $(200 \mathrm{~V})$ for $2.5 \mathrm{~h}$ at a constant temperature of $4^{\circ} \mathrm{C}$. The gel was stained with $0.1 \%$ silver nitrate (Zhang et al., 2007). After polymorphism detection, at least three different PCR products representing each pattern were selected to purify and sequence in the forward and reverse directions. Nucleotide sequence alignments, translations and comparisons were carried out using the Megalign software module of DNASTAR (version 4.0). No polymorphisms were detected in the region of exons 3, 4, 5, 7, and 8 after PCR-SSCP analysis. According to the DNA sequencing, three novel mutations (NC_007314.3: g.577 G>T, $614 \mathrm{~T}>\mathrm{C}, 212237 \mathrm{~T}>\mathrm{C}$ ) were found in exon 2, intron 2 and exon 9, respectively. The sequences had been submitted to GenBank (Nos. GQ203619, GQ292764, and GQ292765).

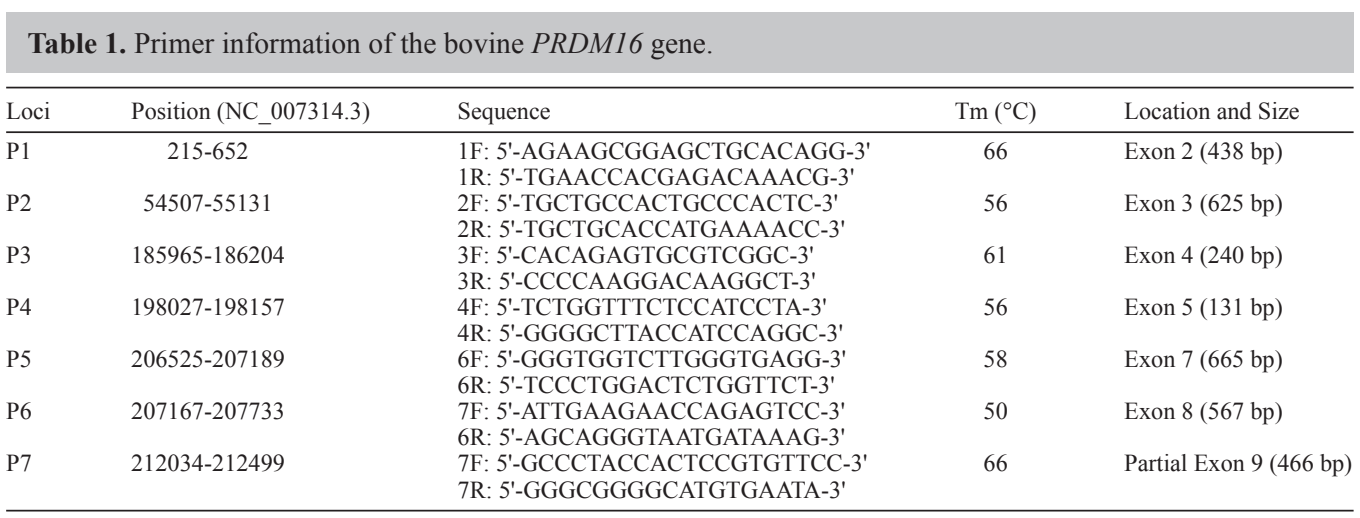




\section{New primers for detecting the g.577 G $>\mathrm{T}$ and $212237 \mathrm{~T}>\mathrm{C}$ mutations}

Since the SSCP method is more complicated and takes a long time, CRS-PCRRFLP was used to detect the g.577 G>T mutations. A new forward primer (P1-1Fnew: 5'-GGTGGCGCCCCGGGCCATGCTGAACGAGCC-3') was designed; it started at position 547 according to GenBank accession No. NC_007314.3. The naturally occurring ' $G$ ' nucleotide at position 575 was substituted by a ' $\mathrm{C}$ ' in the forward primer (underlined) in order to introduce a recognition site (CCGG) for the $M s p$ I restriction endonuclease. The above forward PCR primer (P1-1R) and the new forward PCR primer (P1-1Fnew) were used to obtain PCR products from all cattle. Aliquots of $10 \mu \mathrm{L}$ of the PCR products were digested with $10 \mathrm{U} \mathrm{MspI} \mathrm{(MBI)} \mathrm{for} 8 \mathrm{~h}$ at $37^{\circ} \mathrm{C}$. The digested products were detected by electrophoresis on $3.0 \%$ agarose gel stained with ethidium bromide.

Further study on the g.614 $\mathrm{T}>\mathrm{C}$ mutation was not done because it is located in intron 2 .

The g.212237 T>C mutation added an MspI endonuclease restriction site (CCGG), so a pair of new primers (forward: 5'-CCTACCACTCCGTGTTCCC-3' and reverse: 5'-TCGGCTGCCAATGCTC-3') was designed to detect this mutation more conveniently. The forward primer started at position 212,036 and the reverse primer was at position 212,292, according to GenBank accession No. NC_007314.3. The length of the PCR product was $272 \mathrm{bp}$. Aliquots of $10 \mu \mathrm{L}$ PCR products were digested with $10 \mathrm{U} M s p \mathrm{I}$ (MBI) for $8 \mathrm{~h}$ at $37^{\circ} \mathrm{C}$. The digested products were detected by electrophoresis on $10 \%$ PAGE stained with $0.1 \%$ silver nitrate.

\section{Statistical analysis}

For the g.577 G>T and g.212237 T $>$ C mutations in the bovine PRDM16 gene, differences in genotypic and allelic frequencies among Chinese populations were analyzed using the chi-square test (Table 2), using the SPSS software (version 13.0). According to Nei's methods (Nei and Roychoudhury, 1974), the population genetic indexes [namely, gene homozygosity $\left(H_{\mathrm{O}}\right)$, gene heterozygosity $\left(H_{\mathrm{E}}\right)$, effective allele numbers $\left(N_{\mathrm{E}}\right)$, and polymorphism information content (PIC)] were calculated (Table 3 ).

\begin{tabular}{|c|c|c|c|c|c|c|c|}
\hline \multirow[t]{2}{*}{ Loci } & \multirow[t]{2}{*}{ Breeds } & \multicolumn{3}{|c|}{ Genetypic frequencies } & \multirow[t]{2}{*}{ Total } & \multicolumn{2}{|c|}{ Allelic frequencies } \\
\hline & & GT & GG & TT & & G & $\mathrm{T}$ \\
\hline \multirow[t]{4}{*}{ g. $577 \mathrm{G}>\mathrm{T}$} & $\mathrm{JX}$ & 0.350 & 0.598 & 0.053 & 446 & 0.772 & 0.228 \\
\hline & NY & 0.540 & 0.428 & 0.032 & 269 & 0.698 & 0.302 \\
\hline & QC & 0.448 & 0.508 & 0.044 & 236 & 0.732 & 0.268 \\
\hline & $\mathrm{CH}$ & 0.938 & 0.062 & 0.000 & 80 & 0.969 & 0.031 \\
\hline \multirow[t]{5}{*}{ g.212237 T>C } & & $\mathrm{TC}$ & TT & $\mathrm{CC}$ & Total & $\mathrm{T}$ & $\mathrm{C}$ \\
\hline & JX & 0.527 & 0.209 & 0.264 & 446 & 0.368 & 0.632 \\
\hline & NY & 0.545 & 0.202 & 0.252 & 269 & 0.353 & 0.647 \\
\hline & $\mathrm{QC}$ & 0.546 & 0.053 & 0.401 & 236 & 0.427 & 0.573 \\
\hline & $\mathrm{CH}$ & 0.888 & 0.112 & 0.000 & 80 & 0.944 & 0.056 \\
\hline
\end{tabular}

$\mathrm{JX}=$ Jiaxian; $\mathrm{NY}=$ Nanyang; $\mathrm{QC}=$ Qinchuan; $\mathrm{CH}=$ Chinese Holstein. 
Table 3. PIC, $H_{\mathrm{O}}, H_{\mathrm{E}}$, and $N_{\mathrm{E}}$ at two polymorphic loci of the bovine PRDM16 gene.

\begin{tabular}{lclcccc}
\hline Loci & Breeds & Types & $H_{\mathrm{O}}$ & $H_{\mathrm{E}}$ & $N_{\mathrm{E}}$ & PIC \\
\hline g.577 G $>$ T & JX & Farming and meat & 0.648 & 0.352 & 1.542 & 0.290 \\
& NY & Farming and meat & 0.578 & 0.422 & 1.729 & 0.333 \\
& QC & Farming and meat & 0.608 & 0.392 & 1.646 & 0.315 \\
g.212237 T>C & CH & Dairy and meat & 0.939 & 0.061 & 1.064 & 0.059 \\
& JX & Farming and meat & 0.535 & 0.465 & 1.870 & 0.357 \\
& NY & Farming and meat & 0.543 & 0.457 & 1.841 & 0.353 \\
& QC & Farming and meat & 0.511 & 0.489 & 1.959 & 0.370 \\
& CH & Dairy and meat & 0.894 & 0.106 & 1.119 & 0.101 \\
\hline
\end{tabular}

$\mathrm{PIC}=$ polymorphism information content; $H_{\mathrm{O}}=$ gene homozygosity; $H_{\mathrm{E}}=$ gene heterozygosity; $N_{\mathrm{E}}=$ effective allele number. For breed abbreviations, see Table 2 .

The reduced model was used in the final analysis. The SPSS software (version 16.0) was used to analyze the relationship between the genotypes and traits in cattle. The reduced linear model included fixed effects of age and genotype. The linear model:

$$
\mathrm{Y}_{\mathrm{ijk}}=\mu+\mathrm{A}_{\mathrm{i}}+\mathrm{G}_{\mathrm{j}}+\mathrm{E}_{\mathrm{ijk}} \text {, }
$$

where $Y_{i j k}=$ the trait measured in the $\mathrm{ijk} \mathrm{k}^{\text {th }}$ animal; $\mu=$ the overall population mean; $A_{i}=$ the fixed effect due to the $\mathrm{i}^{\text {th }}$ age; $G_{j}=$ the fixed effect associated with $\mathrm{j}^{\text {th }}$ genotype; $E_{i j k}=$ the random error. The least square means estimates (LSM) with standard errors for different genotypes and growth trait were used.

\section{RESULTS}

\section{PRDM16 gene sequencing}

Comparison with the nucleotide sequence of the bovine PRDM16 gene (GenBank accession No. NC_007314.3), P1 fragment (exon 2 and its flanking region) of the PRDM16 gene revealed two mutations: NC_007314.3: g.577 G>T, $614 \mathrm{~T}>\mathrm{C}$. The g.577 G>T is a synonymous mutation (p.A108A) located at exon 2; namely, Ala(GCG)>Ala(GCT) at position 108. Partial sequencing maps of the three genotypes are shown in Figure 1A. The g.614 T>C was located at intron 2.

A missense mutation was detected in the $\mathrm{P} 7$ fragment (exon 9 and its flanking region; Figure 2A): NC_007314.3: g.212237 T>C (p.L772P), that is Leu(CTG) $>$ Pro(CCG) at position 772.

\section{Detecting the mutations by CRS-PCR-RFLP and PCR-RFLP}

The CRS-PCR-RFLP and PCR-RFLPs methods were successfully carried out to accurately detect the mutations of the bovine PRDM16 gene. For the g.577 G>T mutation, the 106-bp products digested with $M s p I$ demonstrated two fragments (95 and $11 \mathrm{bp}$ ) for the PRDM16-T allele and three fragments (76, 19 and $11 \mathrm{bp}$ ) for the PRDM16-C allele (Figure 1B). Moreover, g.212237 T $>\mathrm{C}$ was genotyped by $M s p \mathrm{I}$ endonuclease. The 272-bp amplified DNA fragment digested with this endonuclease digestion gave four bands $(116,85,47$, and 24 bp) for the PRDM16-C allele and three bands $(116,109$, and $47 \mathrm{bp})$ for the PRDM16-T allele (Figure 2B). It was noted that the 19-, 11-, 47- and 24-bp fragments were too short to be visible (Figure 1B and Figure 2B). 
A
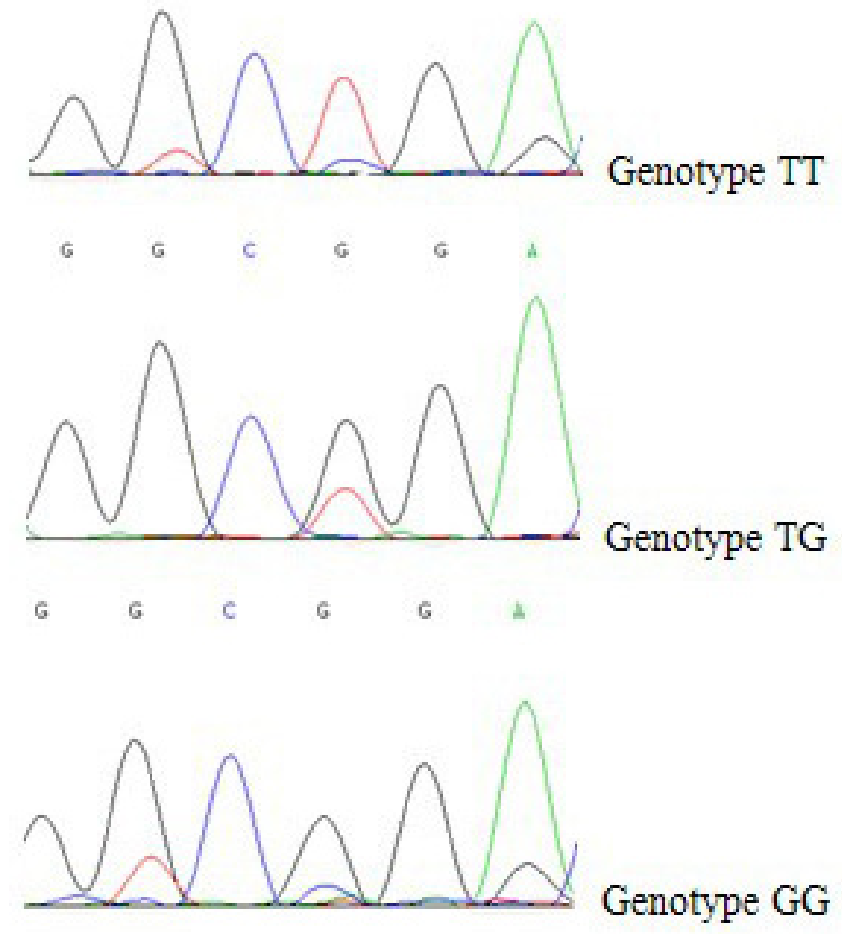

B

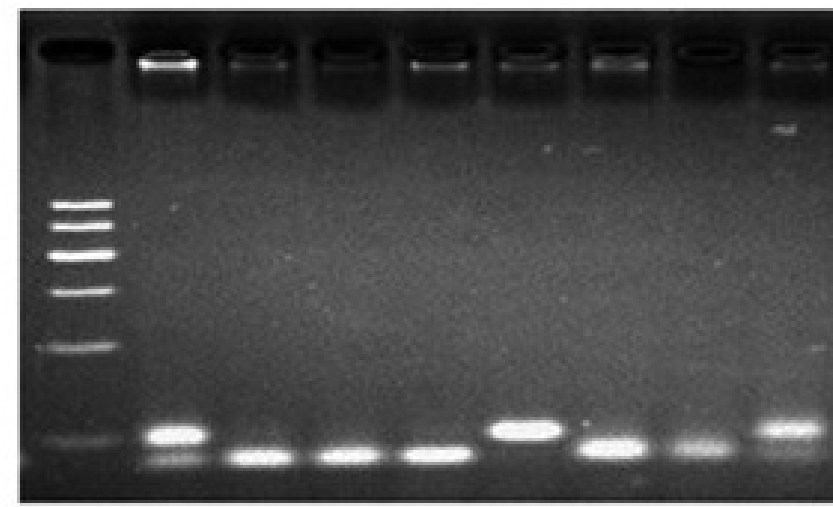

$95 \mathrm{bp}$

$76 \mathrm{bP}$

\section{$M \quad G T \quad G G \quad G G \quad G G \quad T T \quad G G \quad G G \quad G T$}

Figure 1. A. Sequencing maps at position of NW_007314.3: g.577 G>T from different genotypes in the bovine PRDM16 gene. B. Electrophoretic patterns on 3\% agarose gel after digestion with MspI endonuclease of the PCR fragment containing g. $577 \mathrm{G}>\mathrm{T}$ mutation of the bovine $P R D M 16$ gene. TT $=95+11 \mathrm{bp}$. TC $=95+76+19+11 \mathrm{bp}$. $\mathrm{CC}=76+19+11 \mathrm{bp}$. Lane $M=$ molecular marker I $(600,500,400,300,200,100 \mathrm{bp})$. Two framents (11 and $19 \mathrm{bp})$ were too short to be visible. 
A
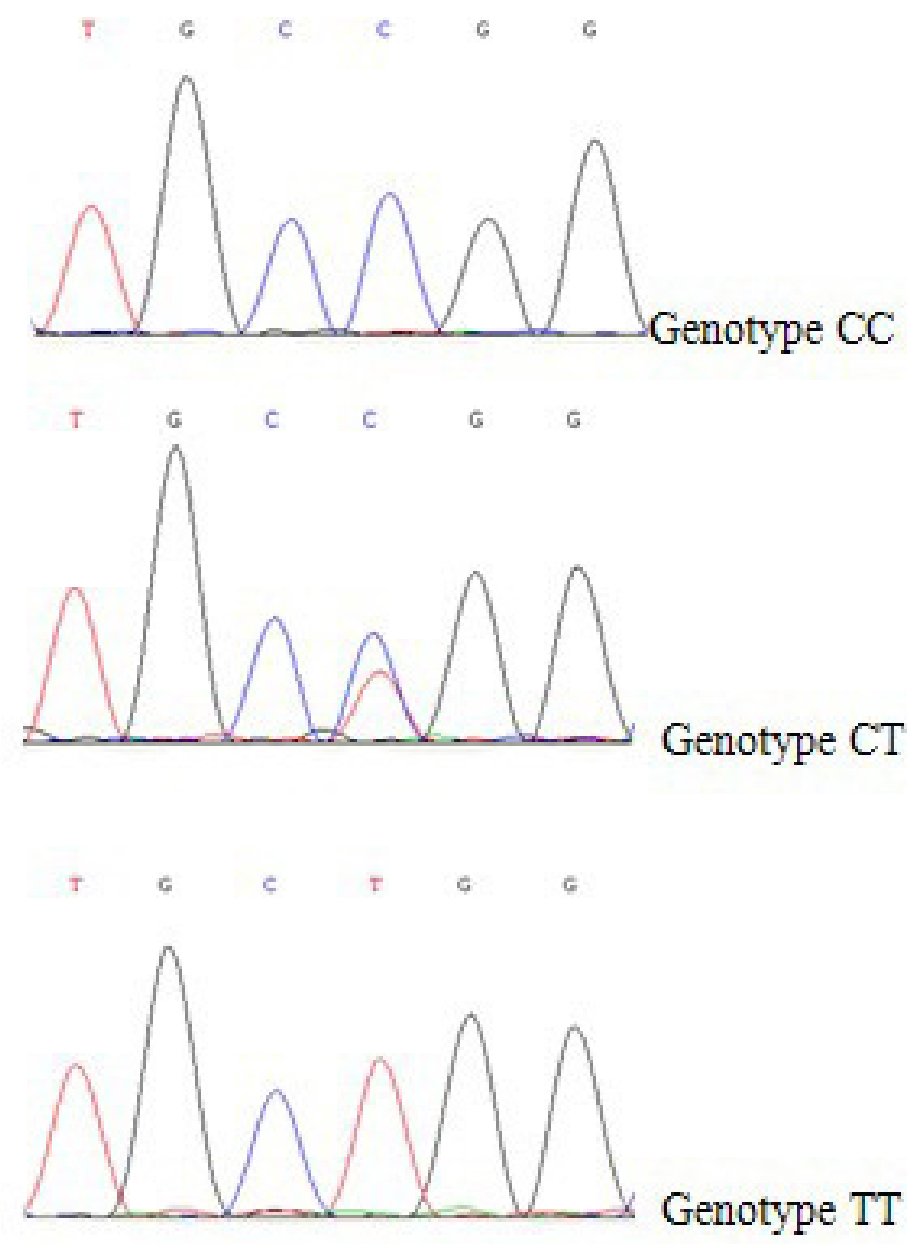

$\mathbf{B}$

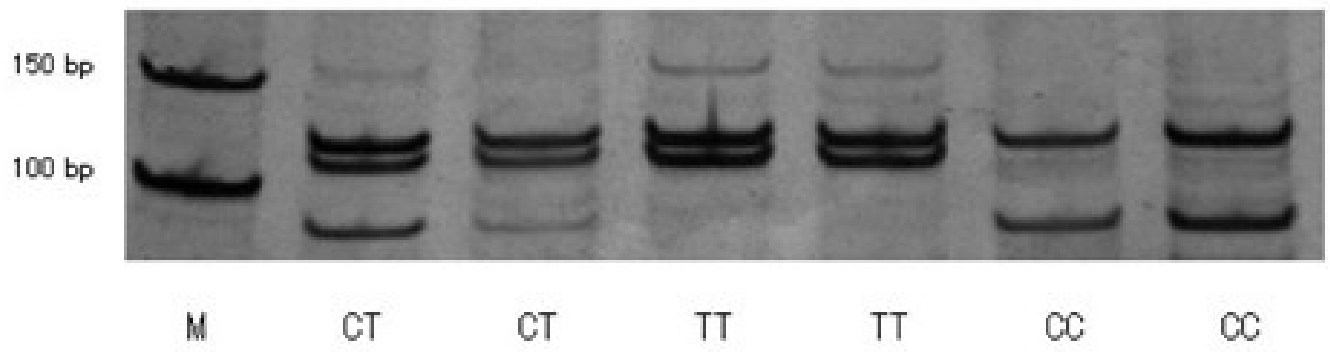

Figure 2. A. Sequencing maps at position of NW_007314.3: g.212237 T $>$ C from different genotypes in the bovine PRDM16 gene. B. Electrophoretic patterns on $10 \%$ PAGE after digestion with $M s p$ I endonuclease of the PCR fragment containing g. $212237 \mathrm{~T}>\mathrm{C}$ of the bovine $P R D M 16$ gene. $\mathrm{TT}=116+109+47 \mathrm{bp} . \mathrm{TC}=116+109+85+47+24$ bp. $C C=116+85+47+24$ bp. Lane $M=50$-bp DNA ladder. Two fragments ( 24 and $47 \mathrm{bp}$ ) were too short to be visible. 


\section{The results of the statistical analysis}

Growth traits (body weight and average daily gain) at birth, 6, 12, 18, 24 months were analyzed in Nanyang cattle. When we examined the g.577 G>T mutation, the animals homozygous for allele GG had significantly greater body weight and average daily gain than those of the homozygous TT genotype animals at six months (Table 4). When we examined the g.212237 T $>C$ mutation, animals with the TT genotype had a higher body weight and average daily gain at six months $(\mathrm{P}<0.05)$. The rest of the growth traits were not significantly associated with these loci $(\mathrm{P}>0.05$; data not shown).

\begin{tabular}{|c|c|c|c|c|c|}
\hline \multirow[t]{2}{*}{ Loci } & \multirow[t]{2}{*}{ Age (months) } & \multirow[t]{2}{*}{ Growth traits $(\mathrm{kg})$} & \multicolumn{3}{|c|}{ Genotypes } \\
\hline & & & GG & GT & TT \\
\hline \multirow[t]{2}{*}{ g. $577 \mathrm{G}>\mathrm{T}$} & 6 & $\begin{array}{l}\mathrm{BW} \\
\mathrm{ADG}\end{array}$ & $\begin{aligned} & 163.000 \pm 1.923^{\mathrm{aA}} \\
& 0.739 \pm 0.010^{\mathrm{a}} \\
&\end{aligned}$ & $\begin{aligned} & 159.727 \pm 2.560^{\mathrm{a}} \\
& 0.720 \pm 0.014^{\mathrm{ab}} \\
&\end{aligned}$ & $\begin{aligned} & 147.333 \pm 5.661^{\mathrm{Bb}} \\
& 0.658 \pm 0.030^{\mathrm{b}} \\
&\end{aligned}$ \\
\hline & & & TT & $\mathrm{TC}$ & $\mathrm{CC}$ \\
\hline g. $212237 \mathrm{~T}>\mathrm{C}$ & 6 & $\begin{array}{l}\text { BW } \\
\text { ADG }\end{array}$ & $\begin{aligned} 161.667 & \pm 2.110^{\mathrm{a}} \\
0.729 & \pm 0.011^{\mathrm{a}}\end{aligned}$ & $\begin{aligned} 161.094 & \pm 2.608^{\mathrm{ab}} \\
0.729 & \pm 0.014^{\mathrm{a}}\end{aligned}$ & $\begin{aligned} 150.571 & \pm 5.075^{b} \\
0.668 & \pm 0.027^{b}\end{aligned}$ \\
\hline
\end{tabular}

$\mathrm{BW}=$ body weight; $\mathrm{ADG}=$ average daily gain. $\mathrm{LSM}$ in a column with no common superscript letters differ significantly; low-case letters represent significance at $\mathrm{P}<0.05$, capital letters represent significance at $\mathrm{P}<0.01$.

\section{DISCUSSION}

\section{Differences in the breeds}

Based on the PIC classification, for both of the loci, three breeds (JX, NY and QC) possessed moderate genetic diversity (Table 3 ). This could be explained by the fact that all samples were from healthy individuals without myelodysplastic syndrome. In contrast, the milk utility breed $(\mathrm{CH})$ had poor genetic diversity; this may have been caused by its breeding program.

As breeds had different types of utility (work, meat and milk), the genotypic distribution was significantly affected by utility type and breeds. In the work and meat utility breeds (JX NY, and QC), no TT and CC genotypes were detected in the g.577 G>T and $212237 \mathrm{~T}>\mathrm{C}$ mutations, respectively. The genotypes TT and CC may be associated with milk production traits.

\section{The effect of synonymous mutations}

For the g.577 G>T (p.A108A) mutation in exon 2, association analysis showed that the individuals with the GG genotype had significantly greater body weight and average daily gain at six months. It is considered that synonymous mutations do not result in codon substitutions, so this kind of mutation is considered a "silent" mutation (Komar, 2007). These silent SNPs do not change the amino acid composition of the protein product, so they have largely been assumed to exert no discernible effect on gene function or phenotype (Oh et al., 2006; Lai et al., 2009; Ren et al., 2010). But recently, in goats, a synonymous mutation of POU1F1 
has been found to be associated with milk yield and birth weight (Lan et al., 2007). Naturally occurring silent SNPs can affect protein folding and consequently in vivo function (KimchiSarfaty et al., 2007). Synonymous SNPs in $A B C B 1$ (P-glycoprotein), implicated both in drug pharmacokinetics and multidrug resistance in human cancer cells, can affect protein conformation and function (Sauna et al., 2007). Thus, we presume that the synonymous mutation (g.577 G>T) changes the style of protein folding or it links to another mutation in the coding or regulatory regions of a gene that affects growth traits.

\section{The association of the observed polymorphism with growth traits in Nanyang cattle}

From the correlation analysis based on the linear model, we found no significant differences in birth weight; thus, these two mutations (NC_007314.3: g.577 G>T, $212237 \mathrm{~T}>\mathrm{C}$ ) apparently do not affect growth traits before birth.

At six months, we find that individuals with the GG genotype in the g.577 G>T mutation and TT genotype in the g.212237 T $>\mathrm{C}$ mutation had greater body weight and average daily gain, respectively.

These results are in agreement with the distribution of the brown fat. Brown fat dissipates energy as heat and plays an important role in the regulation of body temperature and fat metabolism in small and newborn mammals (Cousin et al., 1992). This may be attributed to interactions between PRDM16 and other genes. Previous studies showed that regulated docking of the CtBP proteins on the PRDM16 protein controls the brown and white fat determination (Kajimura et al., 2008).

The PPAR- $\gamma$ gene has regulatory roles in metabolic syndrome, type 2 diabetes mellitus, osteoporosis, atherosclerosis, and lipid metabolism (Walczak et al., 2003; Rosado et al., 2007). Its polymorphisms have been significantly associated with human type 2 diabetes mellitus and body mass index, chicken fatness traits, abdominal fat, and porcine meat quality (Rhee et al., 2006; Yang et al., 2009). In the PRDM16 complex, PPAR- $\gamma$ is the only DNAbinding transcriptional component; the PRDM16 protein stimulates brown adiposeness by binding to PPAR- $\gamma$ and activating its transcriptional function. Thus, the PRDM16 gene was suggested to be associated with bovine growth.

Recently, Chen et al. (2010) detected two silent mutations (GU363953: $1305 \mathrm{G}>\mathrm{A}$ and $1641 \mathrm{~A}>\mathrm{G}$ ) in exon 9 of the caprine PRDM16 gene, and the $1305 \mathrm{G}>\mathrm{A}$ mutation showed significant association with caprine body length, chest circumference and body weight. Thus, the PRDM16 gene may affect growth traits in livestock, and exon 9 has an important role in the function of the PRDM16 gene.

Our results showed that the PRDM16 gene affect body weight and average daily gain in early stage of cattle growth. Further research will be necessary before these SNPs can be used for marker-assisted selection and investigate whether the PRDM16 gene affects growth traits and intramuscular fat deposition.

\section{ACKNOWLEDGMENTS}

Research supported by the National Natural Science Foundation of China (\#30972080), the Keystone Project of Transfergene of China (\#2009ZX08009-157B, \#2008ZX08007-002, 
and \#2009ZX08007-005B-07), and the Program of National Beef Cattle Industrial Technology System (\#CARS-38).

\section{REFERENCES}

Chen H and Leibenguth F (1995). Studies on multilocus fingerprints, RAPD markers, and mitochondrial DNA of a gynogenetic fish (Carassius auratus gibelio). Biochem. Genet. 33: 297-306.

Chen DX, Jin QJ, Fang XT, Zhang CL, et al. (2010). Analysis of the polymorphisms in the caprine PRDM16, SHH and SF-1 genes and their association with production traits in goats. Small Ruminant Res. 93: 193-197.

Cousin B, Cinti S, Morroni M, Raimbault S, et al. (1992). Occurrence of brown adipocytes in rat white adipose tissue: molecular and morphological characterization. J. Cell Sci. 10: 931-942.

Farmer SR (2008). Molecular determinants of brown adipocyte formation and function. Genes Dev. 22: 1269-1275.

Jenuwein T (2001). Re-SET-ting heterochromatin by histone methyltransferases. Trends Cell Biol. 11: 266-273.

Kajimura S, Seale P, Tomaru T, Erdjument-Bromage H, et al. (2008). Regulation of the brown and white fat gene programs through a PRDM16/CtBP transcriptional complex. Genes Dev. 22: 1397-1409.

Kimchi-Sarfaty C, Oh JM, Kim IW, Sauna ZE, et al. (2007). A "silent" polymorphism in the MDR1 gene changes substrate specificity. Science 315: 525-528.

Kinameri E, Inoue T, Aruga J, Imayoshi I, et al. (2008). Prdm proto-oncogene transcription factor family expression and interaction with the Notch-Hes pathway in mouse neurogenesis. PLoS One 3: e3859.

Komar AA (2007). Silent SNPs: impact on gene function and phenotype. Pharmacogenomics 8: 1075-1080.

Lai X, Lan X, Chen H, Wang X, et al. (2009). A novel SNP of the Hesx1 gene in bovine and its associations with average daily gain. Mol. Biol. Rep. 36: 1677-1681.

Lan XY, Pan CY, Chen H and Zhang CL (2007). An AluI PCR-RFLP detecting a silent allele at the goat POU1F1 locus and its association with production traits. Small Ruminant Res. 73: 8-12.

Nedergaard J, Bengtsson T and Cannon B (2007). Unexpected evidence for active brown adipose tissue in adult humans. Am. J. Physiol. Endocrinol. Metab. 293: E444-E452.

Nei M and Roychoudhury AK (1974). Sampling variances of heterozygosity and genetic distance. Genetics 76: 379-390.

Oh I, Shimizu H, Satoh T, Okada S, et al. (2006). Identification of nesfatin-1 as a satiety molecule in the hypothalamus. Nature 443: 709-712.

Ren G, Chen H, Zhang LZ, Lan XY, et al. (2010). A coding SNP of LHX4 gene is associated with body weight and body length in bovine. Mol. Biol. Rep. 37: 417-422.

Rhee EJ, Oh KW, Lee WY, Kim SY, et al. (2006). Effects of two common polymorphisms of peroxisome proliferatoractivated receptor-gamma gene on metabolic syndrome. Arch. Med. Res. 37: 86-94.

Rosado EL, Bressan J, Martins MF, Cecon PR, et al. (2007). Polymorphism in the PPARgamma2 and beta2-adrenergic genes and diet lipid effects on body composition, energy expenditure and eating behavior of obese women. Appetite 49: 635-643.

Sauna ZE, Kimchi-Sarfaty C, Ambudkar SV and Gottesman MM (2007). Silent polymorphisms speak: how they affect pharmacogenomics and the treatment of cancer. Cancer Res. 67: 9609-9612.

Seale P, Kajimura S, Yang W, Chin S, et al. (2007). Transcriptional control of brown fat determination by PRDM16. Cell Metab. 6: 38-54.

Seale P, Bjork B, Yang W, Kajimura S, et al. (2008). PRDM16 controls a brown fat/skeletal muscle switch. Nature 454: 961-967.

Walczak R, Tontonoz P and Edward AD (2003). PPAR[gamma] Signaling in Adipose Tissue Development. In: Handbook of Cell Signaling, Academic Press, Burlington, 39-46.

Wang YH, Bower NI, Reverter A, Tan SH, et al. (2009). Gene expression patterns during intramuscular fat development in cattle. J. Anim. Sci. 87: 119-130.

Warner DR, Horn KH, Mudd L, Webb CL, et al. (2007). PRDM16/MEL1: a novel Smad binding protein expressed in murine embryonic orofacial tissue. Biochim. Biophys. Acta 1773: 814-820.

Yang LL, Hua Q, Liu RK and Yang Z (2009). Association between two common polymorphisms of PPARgamma gene and metabolic syndrome families in a Chinese population. Arch. Med. Res. 40: 89-96.

Zhang C, Wang Y, Chen H, Lan X, et al. (2007). Enhance the efficiency of single-strand conformation polymorphism analysis by short polyacrylamide gel and modified silver staining. Anal. Biochem. 365: 286-287. 